\title{
Reproductive performance of laying snails (Archachatina marginata) fed on roughages and different concentrate mixes
}

\author{
Olatunji Abubakar Jimoh ${ }^{*}$ id and Micheal Olawale Akinola
}

\begin{abstract}
Background: This study aims to investigate the reproduction output of Archachatina marginata fed on roughage and concentrate feed with leaf meal-inclusive diets. One hundred fifty points of lay snails weighing between 150 and $170 \mathrm{~g}$ were randomly allotted to 5 treatment diets with three replicates, ten snails per replicate, designated as treatment 2 (GNCD) which has groundnut cake, treatment 3 (GLLM) has Gliricidia sepium, treatment 4 (MOLM) has Moringa oleifera, and treatment 5 (LLLM) has Leucaena leucocephala leaf meals as protein source in snail diet and a control (treatment 1) (UPWP) fed on roughage (unripe pawpaw and watermelon peel) in a 12-week feed trial. Feed intake, weight gain, egg lay, egg fertility, hatchability, and gonadosomatic index were measured.

Results: The result revealed snails fed with UPWP had the least final weight and weight gain which was accompanied by the highest feed intake across the treatments. Average egg laid, hatchability, fertility, embryo mortality, and average juvenile produced by snails on roughage-based diet were significantly the least across the treatments. High gonadosomatic index of snails on leaf meal-based diet accompanied with better reproductive output in laying snails was recorded.

Conclusion: Snails fed with Leucaena leucocephala-inclusive diet had better egg production, fertility, hatchability, and juvenile snails accompanied with gonadosomatic index across the treatments. Concentrate ration is essential for optimal reproductive output in snails.
\end{abstract}

Keywords: Concentrate supplement, Gonadosomatic indices, Laying snails, Leaf meals, Roughages

\section{Background}

Snail production in Nigeria, like most mini-livestock, is largely rudimentary, and its demand is met by hunting from their habitat in the wild. The natural habitat of African giant land snail is facing deforestation and degradation due to human activities. Hence, there are growing efforts to commercialize snail production to meet the animal protein demand. Large-scale snail farming of African giant land snail (Archachatina marginata) has paved way for it in the international market as well as meeting people's demand for the snail in the local market to the protein intake of the populace (Ejidike and

* Correspondence: abubakarjimoh2011@gmail.com

Agricultural Technology Department, Federal Polytechnic Ado Ekiti, Ado Ekiti, Ekiti State, Nigeria

\section{Springer Open}

Afolayan 2010). Conventional feeds of snail comprise breadfruits, waterleaf, pawpaw leaf and fruit, sweet orange, mango fruit, ripe fruit of plantain and banana, and other feeds of plant origin (Isikwenu 2015). The commercial farming of snails on a continuous basis trespassing the dry seasons through good management practices needs assurance of constant feed supply. Thus, there is the need for alternative cheap and available feedstuff sources, not in competition with other animal species. Limitation of rearing snails includes their very slow growth rate and seasonal breeding pattern, severely limiting their productivity (Eze et al. 2010). This indicates the importance of intensive management and nutrition to induce profitability in snail farming. Concentrate feed or supplements is necessary to optimize the growth and 
productivity of the snail enterprise, as most of the plant food materials are seasonal and do not possess balanced nutrient. The high cost of concentrate ration occasioned by expensive conventional protein feedstuff could reduce the profit margin in snail enterprise. Ejidike and Afolayan (2010) pointed out that the availability of acceptable snail feed could contribute a lot in encouraging interest in snail farming, thereby mitigating the current acute animal protein shortage. However, the use of concentrate ration supplemented with plant materials in feeding snails will arouse the establishment of commercial farming of African giant land snails for constant supply to the market (Oyeagu et al. 2018). It is imperative to investigate non-conventional protein feedstuff such as leaf protein which is abundant and can be processed as feed all year long. Multipurpose browse plants such as Moringa oleifera, Leucaena leucocephala, and Gliricidia sepium leaves are valuable resources high in protein and minerals. This research therefore aimed at comparing the effect of roughage and concentrate feed with Moringa oleifera, Leucaena leucocephala, and Gliricidia sepium leaf meal inclusion in snail diet on reproductive attributes of Archachatina marginata.

\section{Methods}

\section{Experimental protocol}

The study was conducted at the Snail Research unit of Teaching and Research Farm, Department of Agricultural Technology, Federal Polytechnic, Ado Ekiti, Nigeria. The study area is located between latitude $7^{\circ} 3^{\prime}$ $7^{\prime \prime} \mathrm{N}$ and $7^{\prime} 12^{\prime \prime} \mathrm{N}$ and latitude $5^{\circ} 11^{\prime \prime} \mathrm{E}$ and $5^{\circ} 31^{\prime \prime} \mathrm{E}$.

A total of 150 points of lay snails (Archachatina marginata) with $160.25 \pm 5.84$ average body weight and age range 7-8 months were purchased from a farm in Ibadan, Oyo state, Nigeria. Snails were kept in wooden cages with the dimension $30 \mathrm{~cm} \times 40 \mathrm{~cm} \times 24 \mathrm{~cm}$ (height $\times$ length $\times$ width). Feed and water were provided in feeding and water trough. Moringa oleifera, Leucaena leucocephala, and Gliricidia sepium leaf meals were obtained from pasture and forage fields within the teaching and research farm premises. The harvested leaves were shed dried until they were crispy to touch while retaining their greenish coloration. The leaves were then milled to obtain a product herein referred to as Moringa oleifera leaf meal (MLM), Leucaena leucocephala leaf meal (LLM), and Gliricidia sepium leaf meal (GLM). Dietary treatments were formulated GNCD, which contains groundnut cake as protein feedstuff, GLLM has Gliricidia sepium, MOLM has Moringa oleifera, and LLLM has Leucaena leucocephala leaf meals as the protein source in replacement of groundnut cake in snail diet and a control (treatment 1 ) fed on roughage (unripe pawpaw and watermelon peel).
The meals were analyzed for their chemical composition as described by Association of official analytical chemists (1990).

The formulation and chemical composition of experimental diets are shown in Table 1.

One hundred and fifty snails used for this experiment were randomly assigned into five (5) different treatments with three (3) replicates, ten (10) snails per replicate. The cages, drinkers, and feeders were cleaned before the arrival of the snails, the first two (2) weeks for acclimatization of the snails before the experiment will commence. The snails were weighed individually at the start of the experiment, thereafter at the end of each week to determine the weekly live weight gain for the animal. The snails were fed ad libitum; both feeders and drinkers were cleaned before the provision of feed and water. The experiment was conducted for twelve (12) weeks.

Feed intake was determined by finding the difference between the amount of feed supplied and the leftover feed for each replicate. Body weight and body weight gain were measured to know the cumulative differences between the final and initial body weights.

\section{Reproductive performance}

The total number of eggs laid by the snails was determined and recorded. All eggs that did not hatch after the 30th day were collected and opened to determine

Table 1 The formulation of the experimental diet ( $\mathrm{g} / 100 \mathrm{~g}$ )

\begin{tabular}{lllll}
\hline & GNCD & GLLM & MOLM & LLLM \\
\hline Maize & 50 & 50 & 50 & 50 \\
Wheat offal & 27.5 & 27.5 & 27.5 & 27.5 \\
Groundnut cake & 16.5 & - & - & - \\
Gliricidia & - & 16.5 & - & - \\
Moringa & - & - & 16.5 & - \\
Leucaena & - & - & - & 16.5 \\
Bone meal & 3 & 3 & 3 & 3 \\
Oyster shell & 3 & 3 & 3 & 3 \\
Total & 100 & 100 & 100 & 100
\end{tabular}

Nutrient composition of experimental diet

\begin{tabular}{lllll} 
Dry matter (\%) & 83.46 & 74.17 & 72.02 & 72.78 \\
Crude protein (\%) & 17.10 & 13.70 & 14.58 & 14.82 \\
Metabolizable energy (kcal/g) & 2.67 & 2.30 & 2.30 & 2.23 \\
Ether extract (\%) & 3.95 & 3.78 & 5.17 & 3.72 \\
Crude fiber (\%) & 4.16 & 7.15 & 4.17 & 7.01 \\
Ash & 8.52 & 8.71 & 9.05 & 9.11 \\
Nitrogen-free extract & 66.27 & 66.66 & 67.03 & 65.34 \\
Calcium (\%) & 2.23 & 2.35 & 2.40 & 2.51 \\
Phosphorus (\%) & 0.61 & 0.63 & 0.75 & 0.62 \\
\hline
\end{tabular}


the ones with dead embryos and those that were not fertile ab initio. These were counted and recorded. From these, the following parameters were calculated:

$$
\begin{aligned}
& \text { Fertility }(\%)=\frac{\text { No.of eggs that hatched }+ \text { No.of dead }- \text { in }- \text { shell }}{\text { Total no.of eggs laid }} \times 100 \\
& \text { Hatchability }(\%)=\frac{\text { No.of eggs that hatched }}{\text { Total no.of fertile eggs }} \times 100 \\
& \text { Embryo mortality }(\%)=\frac{\text { No.of dead }- \text { in }- \text { shell }}{\text { Total no.of fertile eggs }} \\
&
\end{aligned}
$$

At the end of the feeding trial, four snails were randomly selected from each replicate for organ assessment. The snails were euthanized by fast-freezing them at $20^{\circ} \mathrm{C} / 30 \mathrm{~min}$ (Nica et al. 2015). The foot (edible portion), the shell, and the visceral mass were weighed separately. Organs such as the gastrointestinal tracts, kidney, salivary gland, vagina, oviduct, penis, and mouth were extracted and weighed. Specimens were measured with a Vernier caliper and weighed in the analytical balance with a sensitivity of $0.01 \mathrm{~g}$. The gonadosomatic index was estimated as expressed by Barber and Blake (2006); GSI = gonad weight $\times 100 /$ whole body weight

\section{Statistical analysis}

Data obtained in this study were subjected to analysis of variance at $p=0.05$ using the general linear model procedure of statistical analysis software. Significantly different means were separated with New Duncan's multiple range test of statistical analysis software (2011).

\section{Results}

The reproductive performance of laying snails fed with different treatments is shown in Table 2. The initial weight was similar across the treatments, indicating homogeneity in randomizing and allotting snails to treatment. The final weight, weight gain, feed intake, the average egg laid, hatchability, fertility, embryo mortality, and average juvenile snails were significantly $(p<0.05)$ affected by the diets offered to snails. The shell changes were not statistically $(p>0.05)$ influenced by the treatments.

The final weight of snails on T2 to T5 was statistically $(p>0.05)$ similar and significantly $(p<0.05)$ higher than snails on T1. The weight gain of snails on T2 was significantly $(p<0.05)$ highest and the least value was obtained in T1. Snails on leaf meal-inclusive diets (T3-T5) had statistically $(p>0.05)$ similar weight gain. The feed intake of snails on T2-T5 was statistically $(p>0.05)$ similar and significantly $(p<0.05)$ lower than snails on T1.

The average egg laid per snails reveal that snails on leaf meal-inclusive diets (T3-T5) had statistically ( $p<$ $0.05)$ higher value and the significantly $(p<0.05)$ least values were obtained in snails fed with T1. Egg hatchability of snails on T4 and T5 were significantly $(p<$ 0.05 ) higher than snails on treatments 2 and 3. Fertility of eggs was significantly $(p<0.05)$ highest in snails on T5 and least in snails on T1. Embryo mortality was statistically $(p>0.05)$ similar in snails on concentratebased diets (T2-T5) and was significantly $(p<0.05)$ lower than snails on T1. The average juvenile snails were statistically $(p>0.05)$ similar in snails on leaf mealinclusive diets (T3-T5) and significantly $(p<0.05)$ higher than snails on GNCD-inclusive diets.

Reproductive organ weights of laying snails fed with different treatments are shown in Table 3. All parameters assessed were significantly $(p<0.05)$ affected by the treatments except GIT weight. The shell weight was significantly $(p<0.05)$ higher in treatments 2 and 4 than the other treatments. The carcass weight was significantly $(p<0.05)$ least in T1 followed by T4. The foot weight was significantly $(p<0.05)$ least in snails on T1, followed by treatment 3 , and significantly $(p<0.05)$ highest value was obtained in snails on T4. The penis of snails on T2-T5 was statistically $(p<0.05)$ higher than

\begin{tabular}{|c|c|c|c|c|c|c|c|}
\hline & UPWP & GNCD & GLLM & MOLM & LLLM & \pm SEM & $p$ value \\
\hline Initial weight (g/snail) & 153.57 & 165.53 & 156.33 & 151.27 & 174.53 & 3.75 & 0.83 \\
\hline Final weight (g/snail) & $211.36^{b}$ & $259.45^{\mathrm{a}}$ & $241.16^{\mathrm{a}}$ & $246.00^{\mathrm{a}}$ & $259.26^{a}$ & 7.70 & 0.04 \\
\hline Weight gain (g/d/snail) & $0.69^{c}$ & $1.24^{\mathrm{a}}$ & $1.13^{\mathrm{b}}$ & $1.13^{b}$ & $1.01^{\mathrm{b}}$ & 0.03 & 0.03 \\
\hline Feed intake (g/snail/day) & $4.87^{\mathrm{a}}$ & $2.69^{b}$ & $2.62^{b}$ & $2.60^{b}$ & $2.6 .0^{b}$ & 0.30 & 0.03 \\
\hline Average egg laid per snail & $2.26^{\mathrm{c}}$ & $5.07^{b}$ & $8.13^{\mathrm{a}}$ & $6.07^{\mathrm{ab}}$ & $6.87^{\mathrm{ab}}$ & 2.07 & 0.04 \\
\hline Hatchability of eggs (\%) & $60.47^{c}$ & $82.35^{b}$ & $83.76^{b}$ & $90.48^{\mathrm{a}}$ & $93.20^{\mathrm{a}}$ & 3.26 & 0.01 \\
\hline Fertility of eggs (\%) & $66.15^{d}$ & $74.73^{c}$ & $76.97^{c}$ & $82.35^{\mathrm{b}}$ & $94.50^{\mathrm{a}}$ & 2.84 & 0.03 \\
\hline Embryo mortality & $39.53^{\mathrm{a}}$ & $17.65^{\mathrm{b}}$ & $16.24^{b}$ & $9.52^{b c}$ & $6.80^{c}$ & 5.05 & 0.03 \\
\hline No. of juveniles per snail & $1.21^{\mathrm{c}}$ & $3.55^{\mathrm{b}}$ & $7.97^{\mathrm{a}}$ & $5.29^{\mathrm{ab}}$ & $6.88^{\mathrm{a}}$ & 0.86 & 0.02 \\
\hline
\end{tabular}
snails on T. Oviduct weight of snails on T5 was

Table 2 Reproductive performance of laying snails fed with roughages and concentrate with different leaf proteins

abc: means along the same row with different superscripts are significantly $(p<0.05)$ different 
Table 3 Reproductive organ weights of laying snails fed with roughages and concentrate with different leaf proteins

\begin{tabular}{|c|c|c|c|c|c|c|c|}
\hline & UPWP & GNCD & GLLM & MOLM & LLLM & \pm SEM & $p$ value \\
\hline Shell weight (g) & $43.50^{b}$ & $49.98^{a}$ & $41.76^{b}$ & $46.48^{\mathrm{a}}$ & $43.89^{b}$ & 1.80 & 0.04 \\
\hline Carcass weight (g) & $95.50^{c}$ & $138.29^{a}$ & $126.40^{\mathrm{ab}}$ & $118.75^{b}$ & $139.54^{\mathrm{a}}$ & 4.73 & 0.03 \\
\hline Edible weight (g) & $39.11^{c}$ & $86.83^{\mathrm{a}}$ & $79.84^{\mathrm{ab}}$ & $94.23^{b}$ & $82.61^{\mathrm{ab}}$ & 3.16 & 0.03 \\
\hline GIT weight (g) & 28.56 & 30.12 & 31.42 & 28.69 & 31.90 & 0.59 & 0.24 \\
\hline Penis (g) & $1.06^{\mathrm{b}}$ & $1.98^{\mathrm{a}}$ & $2.06^{\mathrm{a}}$ & $1.54^{\mathrm{ab}}$ & $1.57^{\mathrm{ab}}$ & 0.09 & 0.04 \\
\hline Oviduct (g) & $4.36^{b}$ & $2.63^{b}$ & $4.24^{b}$ & $4.42^{b}$ & $10.21^{\mathrm{a}}$ & 0.92 & 0.04 \\
\hline Vagina (g) & $0.16^{\mathrm{b}}$ & $0.37^{\mathrm{a}}$ & $0.35^{\mathrm{a}}$ & $0.25^{b}$ & $0.41^{\mathrm{a}}$ & 0.04 & 0.03 \\
\hline
\end{tabular}

abc: means along the same row with different superscripts are significantly $(p<0.05)$ different

significantly $(p<0.05)$ highest, and other treatments share statistically $(p>0.05)$ similar values. Vagina weight of treatments 1 and 4 are statistically similar $(p<0.05)$ but are significantly $(p<0.05)$ lower than snails on other treatments.

The gonadosomatic index of snails fed with different dietary treatments is shown in Fig. 1. Snails on T5 had the significantly $(p<0.05)$ highest value, and the significantly $(p>0.05)$ least value is obtained in T2. Treatments 1,3 , and 4 have statistically $(p>0.05)$ similar values.

\section{Discussion}

The trend reveals that snails fed with UPWP had the least final weight and weight gain which was accompanied by the highest feed intake across the treatments. This indicates nutritional inadequacy; despite the high feed intake, it could not meet its requirement for growth. This summarizes the call for the balanced nutrient formulation to meet the production requirement of snails.
This is important to enhance growth rate and reproduction in snails. Similarly, the average egg laid, hatchability, fertility, embryo mortality, and average juvenile produced by snails on roughage-based diet were significantly the least across the treatments. Thompson and Sheldon (2004) also reported that poor nutrition affects snail growth and causes a drop in the reproductive performance; this is evident in the result of laying snails fed roughage/natural plant material (UPWP) which had the least reproductive performance as compared to concentrate GNCD-LLLM-fed snails. According to Amaefule and Onwudike (2000), Ani and Okeke (2003), Esonu et al. (2003), Oyeagu et al. (2015), and Oyeagu et al. (2018), the most important factor influencing the performance of animals under captivity is the quality of diet offered to the animals. This study corroborates the claim of Nyameasem and Borketey-La (2014) that layer mash (a concentrate ration) supported reproduction in the snails better than pawpaw fruit diet which gave the poorest result. This is attributed to the report that

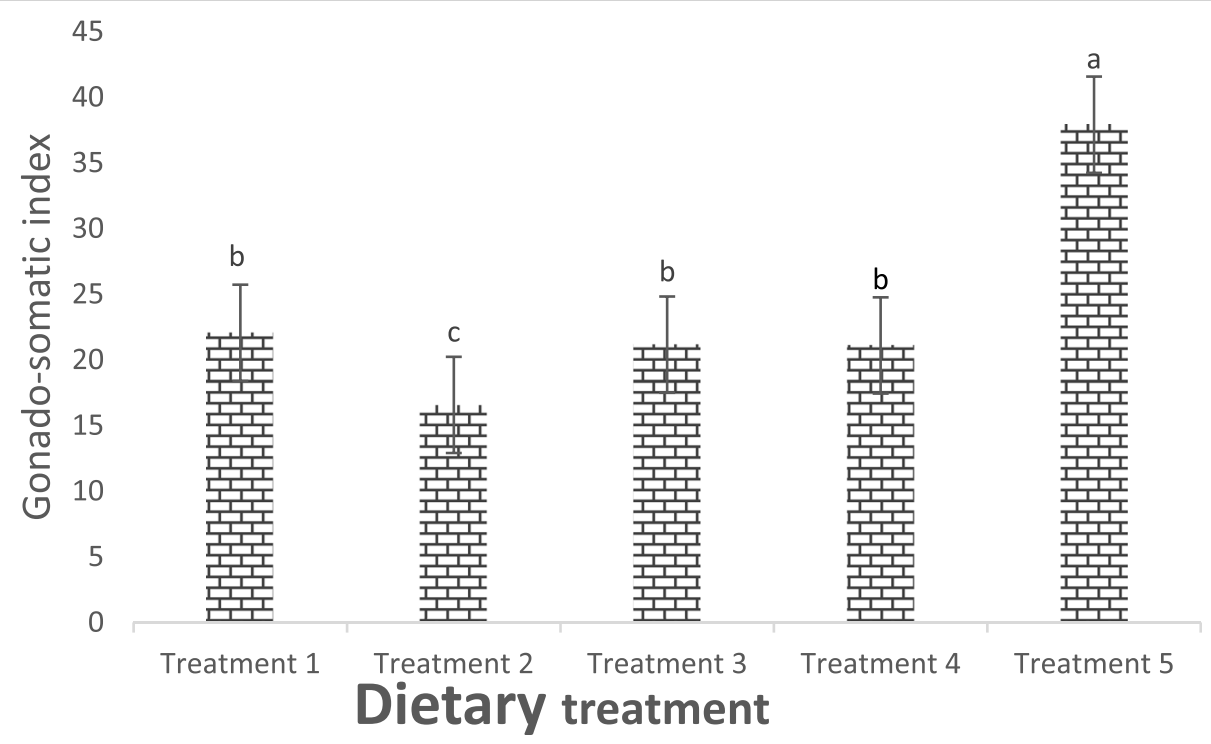

Fig. 1 Gonadosomatic index of laying snails fed with roughages and concentrate with different leaf proteins. abc: means with different superscripts are significantly $(p<0.05)$ different 
pawpaw fruit as a sole diet is not nutritionally balanced enough to meet snails' requirements for reproduction.

The reproductive traits of laying snails fed with concentrate-based feeds (GNCD-LLLM) were superior to plant/roughage-fed snails. Nyameasem and BorketeyLa (2014) reported that snails on compounded diets showed remarkable performance in terms of growth and reproduction over snails fed with pawpaw fruit diet. This might be due to the fact that available nutrients of the diets originate from different feedstuffs thereby making them more balanced.

Egg hatchability, the fertility of eggs, and average juvenile snails of snails fed on leaf meal-inclusive diets were superior to concentrate-fed snails without leaf meal inclusion; this suggest the beneficial ability of the leaf meals to influence reproduction positively. This corroborates other reports in rabbit poultry that leaf meals enhance reproduction and fertility (Ewuola et al. 2012). The result of this study is in agreement with Ejidike (2007) and Oyeagu et al. (2018) that snails fed with diets containing concentrate feed and herbs performed better than those that received only concentrate or herbs. Similarly, Oyeagu et al. (2018) reported that inclusion of $C$. pubescens in concentrate ration for snails increased the number of eggs laid, hatchability, and fertility of eggs with a lesser mortality of the embryo.

The result of this study is in agreement with Ejidike et al. (2002) that both growth and reproductive performance of African giant land snails (A. marginata) were better when their diets are supplemented with natural plant food materials than the snails that were placed on pure concentrate diets.

The concentrate ration enhanced reproductive organ development and the inclusions of leaf meals also contributed to organ development compared to laying snails on natural plant feed/roughage. However, the gonadosomatic index of snails on herbs and roughage treatment was better than snails on concentrate without leaf meal inclusion. The reproductive ability of snails is predicted by the gonadosomatic index; this explains the high gonadosomatic index of snails on leaf meal-based diet accompanied with better reproductive output in laying snails. However, the standout performer is snails fed with Leucaena leucocephala-inclusive treatment, judging by their egg production, fertility, hatchability, and juvenile snails accompanied with gonadosomatic index.

\section{Conclusion}

Concentrate diet is essential for optimal reproductive output in snails. The conventional belief that snails are herbivores and can survive on herbs and roughage is for maintenance requirement. Productive functions such as egg laying and snailet production require concentratebased feeding to improve growth and offspring production, especially for commercialization. The importance of leaf meals to snails as herbivores is demonstrated in this study; laying snails fed with leaf mealinclusive diets have the higher reproductive ability.

\section{Abbreviations}

GSI: Gonadosomatic index; MLM: Moringa oleifera leaf meal; LLM : Leucaena leucocephala leaf meal; GLM: Gliricidia sepium leaf meal; UPWP: Unripe pawpaw and watermelon peel

\section{Authors' contributions}

Jimoh Olatunji Abubakar designed the study and carried out the experimental protocol and statistical analysis. He wrote the first draft. Akinola Micheal Olawale conceptualized the study, supervised the field work, and earned the sponsorship for the study. The authors read and approved the final manuscript.

\section{Funding}

The research outcome presented in this article was funded by TETFUND 2016 institution-based research intervention of the Nigeria government.

\section{Availability of data and materials}

The datasets used and/or analyzed during the current study are available from the corresponding author on reasonable request.

\section{Ethics approval and consent to participate}

The study was approved by the institutional committee on the care and use of animals for experiment and in accordance with $\mathrm{NIH}$ guide for the care and use of laboratory animals.

\section{Consent for publication}

Not applicable

\section{Competing interests}

No competing interest exists in the research outcome presented in this article.

Received: 22 April 2020 Accepted: 8 July 2020

Published online: 16 July 2020

\section{References}

Amaefule KU, Onwudike OC (2000) Evaluation of processing methods of, pigeonpea seeds (Cajanus cajan) as protein source for broiler starters. Journal of Sustainable Agriculture and Environment 2(1):134-138

Ani, A.O. and Okeke GC (2003). The substitution of pigeon pea (Cajanus cajan) seed meal for soybean in broiler finisher ration. Proceedings of the 8th Annual Conference of Animal Science Association of Nigeria, p. 10-12.

Association of official analytical chemists (1990) Official methods of analysis. 15th Edition published by AOAC Inc. USA

Barber, B.J. and Blake N.J. (2006). Reproductive Physiology. In Scallops: Biology, ecology and aquaculture, second Edition, S.E Shumway and G.J. parsons, eds. Elsevier science publisher.

Ejidike BN (2007) Influence of artificial diet on captive rearing of African giant land snail Archachatina marginata pulmonata: Stylommatophora. J Anim Vet Adv 6(8):1028-1030

Ejidike B.N., Afolanyan T.A., and Alokan J.A. (2002). Influence of food and season on egg production of African giant land snail (Archachatina marginata) Proceedings of the 27th Annual Conference of Nigerian Society of Animal Production; Mar 17-21; Akure, Nigeria: Federal University of Technology. p. 309-311.

Ejidike BN, Afolayan TA (2010) Effects of natural and compounded rations on the growth performance of African giant land snail (Archachatina marginata). Journal of research in forestry, wildlife and environment 2(1):107-111

Esonu BO, Lheukwumere FC, Lwuji TC, Akanu N, Nwugo OH (2003) Evaluation of Microdermis puberula leaf meal as feed ingredient in broiler starter diet. Nigeria Journal of Animal Production 30(1):3-8

Ewuola EO, Jimoh OA, Atuma OV, Soipe OD (2012) Growth indices and apparent nutrient digestibility in rabbits fed graded levels of Moringa leaf meal. Nigerian Journal of Animal Science 14:92-100 
Eze JN, Eruvbetine D, Akpodiete OJ, Okonkwo JC (2010) Feeding pattern, carcass and shell qualities of snails (Archachatina marginata) fed different material. Int J Innov Res Sci Eng Technol 1(1):111-121

Isikwenu JO (2015) Pattern of the effect of different vegetable diets supplemented with concentrate on the growth performance of African giant land snail (Archachatina marginata). Int. J. Livest. Res. 5(7):24-32

Nica DV, Filimon MN, Bordean DM, Harmanescu M, Draghici GA, Dragan S (2015) Impact of soil cadmium on land snails: a two-stage exposure approach under semi-field conditions using bioaccumulative and conchological endpoints of exposure. PLoS One 10(3):e0116397 https://doi.org/10.1371/journal. pone.0116397

Nyameasem JK, Borketey-La EB (2014) Effect of formulated diets on growth and reproductive performance of the West African giant snail (Achatina achatina). J. Agric. Biol. Sci 9(1):1-6

Oyeagu CE, Ani AO, Egbu CF, Udeh FU, Omumuabuike JN (2015) Comparative performance of Nera Black and Shaver Brown hen fed self-compounded and commercial layers' diet. Asian Journal Science Technology 6(1):940-946

Oyeagu CE, Udeh FU, Uzochukwu IE, Osita CO, Ugwu SOC, Agugom OH (2018) Effect of dietary Centrosema pubescens leaf meal on growth and reproductive traits of Archachatina marginata snails. J Appl Animal Res 46(1):947-952

Thompson R. and Sheldon C. (2004). Raising snails. Special reference briefs (National Agricultural Library)' Beltsville: United State Department of Agriculture (USDA). p. 96-105.

\section{Publisher's Note}

Springer Nature remains neutral with regard to jurisdictional claims in published maps and institutional affiliations.

\section{Submit your manuscript to a SpringerOpen ${ }^{\circ}$ journal and benefit from:}

- Convenient online submission

- Rigorous peer review

- Open access: articles freely available online

High visibility within the field

- Retaining the copyright to your article

Submit your next manuscript at $\boldsymbol{\nabla}$ springeropen.com 